STUDIA I PRACE WYDZIAŁU NAUK EKONOMICZNYCH I ZARZĄDZANIA nr 41, t. 2

\title{
Maria Słomińska-Okła*
}

doktorantka Uniwersytetu Łódzkiego

\section{ROZWÓJ SYSTEMU ZARZADZZANIA INNOWACJAMI DETERMINANTĄ WZROSTU KONKURENCYJNOŚCI REGIONU}

\begin{abstract}
Streszczenie
Przedmiotem rozważań w artykule jest wpływ systemu zarządzania innowacjami na wzrost konkurencyjności regionów. Analizując literaturę przedmiotu, zwrócono uwagę na znaczenie systemów innowacyjności na poziomie regionalnym.
\end{abstract}

Słowa kluczowe: determinanty wzrostu konkurencyjności regionów, Regionalny System Innowacyjności, zarządzanie innowacjami

\section{Wprowadzenie}

Poziom rozwoju gospodarczego poszczególnych regionów Polski jest bardzo zróżnicowany i towarzyszy temu ich niski poziom innowacyjności. Koncentracja przestrzenna zjawisk depresji i bezrobocia oddziałuje negatywnie na rozwój. Regiony niemające odpowiedniej infrastruktury są opóźnione gospodarczo, przez co nie są atrakcyjne dla przedsiębiorców, a to pociąga za sobą niską innowacyjność i konkurencyjność.

Wśród celów polityki regionalnej państwa jest zmniejszenie zróżnicowania w poziomie rozwoju regionalnego, a jednym z najbardziej efektywnych sposobów osiągnięcia tego celu jest wybór proinnowacyjnego modelu rozwoju.

* E-mail: msokla@interia.pl 
Celem niniejszego opracowania jest określenie możliwości i ograniczeń oddziaływania systemu zarządzania innowacjami na wzrost konkurencyjności regionu.

\section{Regionalne aspekty w zarządzaniu innowacjami}

Kluczową stymulantą prawidłowego funkcjonowania gospodarki jest zdolność do podnoszenia poziomu innowacyjności na poziomie przedsiębiorstw czy regionu. $\mathrm{Z}$ badań wynika ${ }^{1}$, że generalnie niskiemu poziomowi innowacyjności w Polsce towarzyszy jego silne zróżnicowanie pomiędzy poszczególnymi regionami.

Bazowym elementem wzrostu konkurencyjności regionu jest system zarządzania innowacjami, który powinien stanowić jedno z ogniw ekonomiczno-organizacyjnego mechanizmu proinnowacyjnego rozwoju.

W dobie globalizacji, gdy innowacyjność regionu stanowi podstawę konkurencyjności gospodarki, tak istotne staje się tworzenie otoczenia sprzyjającego powstawaniu i rozwijaniu innowacji. Samorządy województw dysponują dokumentami strategicznymi (Strategie Rozwoju Województw oraz Regionalne Strategie Innowacji), które są ukierunkowane na tworzenie i wzmacnianie regionalnych systemów innowacji, a określone w nich cele - kompatybilne ze Strategią Europa 2020, Krajową Strategią Rozwoju Regionalnego, a także inicjatywą „Unia innowacji”.

Prowadzona w kraju polityka regionalna ma na celu wyrównywania szans rozwojowych regionów oraz dążenie do spójności ekonomiczno-społecznej i terytorialnej w skali kraju i poszczególnych województw. Podstawowe dokumenty strategiczne - Strategie Rozwoju Województwa, a szczególnie Regionalne Strategie Innowacji (RSI) - wyznaczały kierunki wspierania innowacyjności w perspektywie finansowej obejmującej okresy 2004-2006, 2007-2013 (ZPORR i SPO Wzrost Konkurencyjności Przedsiębiorstw), a także w obecnej perspektywie finansowej UE na lata 2014-2020 (np. w ramach programów krajowych: PO Innowacyjna Gospodarka, PO Kapitał Ludzki) oraz dziewięć regionalnych programów operacyjnych.

Aby proces mógł stać się bardziej efektywny, musi być odpowiednio zarządzany. Dotyczy to również zarządzania innowacjami. Konieczne jest opracowanie takiego systemu zarządzania, by przedsięwzięcie osiągnęło zamierzony cel. Mowa tu o opracowaniu modelu, który uwzględniłby poszczególne etapy działa-

\footnotetext{
S. Chung, Building a national innovation system through regional innovation systems, http://www.researchgate.net/publication/222883059_Building_a_national_innovation_system_through_regional_innovation systems, s. 485-491 [dostęp 3.05.2015].
} 
nia, począwszy od planowania, przez organizowanie, motywowanie, na kontroli skończywszy. Zarządzanie innowacjami powinno być skierowane na wszystkie zasoby organizacyjne, w tym ludzkie, finansowe, rzeczowe i informacyjne.

W literaturze przedmiotu spotyka się różne modele zarządzania innowacjami. Wyróżnia się wśród nich: 1) model Pavitta i Tidda oraz Bessanta - w którym proces innowacji uwarunkowany jest przez wykazywanie przez przedsiębiorstwo cech innowacyjnej organizacji oraz posiadanie strategii innowacji ${ }^{2}$;2) model Łunarskiego - punktem wyjścia są źródła (zmiany), a kolejnymi etapami: ograniczenia (zasoby), zarządzanie (możliwości), konkurencyjność (potencjał) oraz wyniki (innowacje) ${ }^{3}$; 3) model siedmiokąta zarządzania innowacjami Karlika mający siedem osi odpowiadających poszczególnym sferom zarządzania innowacjami ${ }^{4}$; 4) model The Management Innovation Index (MIX) - mający cztery osie odpowiadające poszczególnym obszarom zarządzania innowacjami: strategii organizacji, praktyce zarządzania, postawom pracowników oraz kulturze organizacyjnej i środowisku pracy 5 .

Wśród wielu pojęć innowacji wyróżnia się definicję sformułowaną przez O'Sullivana, która wskazuje na procesowe i twórcze aspekty innowacji ${ }^{6}$. Innowacje są działaniem składającym się z czynności pozwalających na przekształcenie wartości wejściowych w wartości wyjściowe.

Ze względu na specyfikę procesów innowacji, ich nieliniowy przebieg oraz wielostrumieniowość rozumianą jako równoległa realizacja działań dla kilku alternatyw oraz wysokie ryzyko trudno jest podciągnąc procesy innowacyjne pod jeden standard - wymagają one indywidualnego podejścia. Proces innowacji powinien być wspomagany zarządzaniem procesowym oraz systemowym podejściem do zarządzania, które oznacza planowanie realizacji procesów, zbudowanie możliwie najwydajniejszej struktury systemu, zrozumienie współzależności procesów w systemie oraz ich nieustanne doskonalenie poprzez pomiary i ocenę ${ }^{7}$.

Cele wytyczone w RSI w największym zakresie koncentrują się na interwencji w obszarach związanych z rozwojem ośrodków innowacji i przedsiębiorczości oraz stymulowaniem i promocją przedsiębiorczości technologicznej.

2 J. Bessant, K. Pavitt, J. Tidd, Managing Innovation-Integrating Technological, Market and Organizational Change, Wiley and Sons, Chichester 2005, s. 68.

3 J. Łunarski, System zarzadzania innowacjami, w: Zarzadzanie innowacjami - system zarzadzania innowacjami, Oficyna Wydawnicza Politechniki Rzeszowskiej, Rzeszów 2007, s. 173.

4 M. Karlik, Zarzadzanie innowacjami w przedsiębiorstwie, Poltext, Warszawa 2012, s. 136-151.

https://pl.wikipedia.org/wiki/Zarz\%C4\%85dzanie_innowacjami [dostęp 3.05.2015].

D. O'Sullivan, L. Dooley, Applying innovation, SAGE Publications, Thousand Oaks 2008, s. 47-51.

7 A. Kucińska-Landwójtowicz, Podejście procesowe w zarządzaniu innowacjami, Oficyna Wydawnicza Politechniki Opolskiej, Opole 2013, http://www.ptzp.org.pl/files/konferencje/kzz/artyk_pdf_2013/p016.pdf [dostęp 10.05.2015]. 
W chwili obecnej wyodrębnia się w Polsce jedenaście województw, w których powołane struktury (przewidziane w dokumencie RSI) pełnią wszystkie funkcje zarządcze (planowania, organizowania, motywowania i kontroli) ${ }^{8}$. Istnieją jednak regiony ze zbudowanymi strukturami niepełnymi, których kompetencje obejmują jedynie realizację funkcji motywowania i kontroli. Istnieją także trzy regiony, w których nie stwierdza się funkcjonowania struktur odpowiedzialnych za realizację którejkolwiek z czterech funkcji zarządzania9 ${ }^{9}$

\section{Zróżnicowanie innowacyjności i konkurencyjności regionów w Polsce}

W literaturze przedmiotu innowacyjność badana jest na różnych poziomach. Z punktu widzenia mikroekonomicznego bada się innowacyjność przedsiębiorstw (działania zapewniające sukces biznesowy, przewagę konkurencyjną), w płaszczyźnie mezo- i makroekonomicznej innowacyjność regionów i całego kraju.

Do oceny poziomu innowacyjności regionów należy posłużyć się różnymi wskaźnikami, gdyż ograniczenie się wyłącznie do jednego miernika zawęziłoby znacząco zakres analizy. Wynika to $\mathrm{z}$ faktu, że poziom innowacyjności jest determinowany przez różnorodne czynniki. Dlatego uwzględnia się nakłady na działalność badawczo-rozwojową, zasoby ludzkie uczestniczące w tworzeniu innowacji oraz efekty działalności innowacyjnej ${ }^{10}$. Regiony w Polsce cechują się różnym potencjałem. Analizując dane statystyczne poszczególnych województw w Polsce, zauważa się relacje pomiędzy ich wielkością PKB a poziomem innowacyjności. W tabeli 1 zestawiono produkt krajowy brutto per capita województw w Polsce w 2012 roku wyrażony w cenach bieżących oraz wskaźnik miary syntetycznej innowacyjności „,na wejściu i wyjściu”. Największą wartość PKB per capita odnotowano w województwie mazowieckim - $68299 \mathrm{mln}$ zł, dolnośląskim - 47056 mln zł, śląskim - $43864 \mathrm{mln}$ zł, wielkopolskim - $43466 \mathrm{mln}$ zł, a najniższą wartość PKB per capita osiągnięto w województwie podkarpackim $27719 \mathrm{mln}$ zł.

\footnotetext{
B. Plawgo i in., Regionalne Systemy Innowacji w Polsce. Raport z badań, PARP, Warszawa 2013, s. 64.

Tamże, s. 65.

10 Tamże, s. 49-50.
} 
Tabela 1. PKB per capita województw w Polsce w 2012 roku oraz wskaźnik miary syntetycznej „na wejściu i wyjściu”

\begin{tabular}{|c|c|c|c|}
\hline \multirow{3}{*}{ Województwa } & \multirow{2}{*}{$\begin{array}{c}\text { PKB per capita } \\
\text { (ceny bieżące w mln zł) }\end{array}$} & \multicolumn{2}{|c|}{ Miara syntetyczna } \\
\hline & & \multirow{2}{*}{ "na wejściu" } & \multirow{2}{*}{ "na wyjściu” } \\
\hline & 2012 & & \\
\hline Dolnośląskie & 47056 & 3 & 0,812232262 \\
\hline Kujawsko-pomorskie & 33803 & $-0,138695066$ & $-0,399125389$ \\
\hline Lubelskie & 34227 & $-0,19582892$ & $-0,044388132$ \\
\hline Lubuskie & 34227 & $-0,879331425$ & $-0,433617532$ \\
\hline Łódzkie & 38418 & 0,281163053 & $-0,527156416$ \\
\hline Małopolskie & 35271 & 0,470312171 & 0,476006097 \\
\hline Mazowieckie & 68299 & 1,66574203 & 0,919513148 \\
\hline Opolskie & 32813 & $-0,630500603$ & 0,300359656 \\
\hline Podkarpackie & 27719 & 0,304838545 & 0,418081946 \\
\hline Podlaskie & 29356 & $-0,597100225$ & $-0,432083624$ \\
\hline Pomorskie & 39917 & 0,25599445 & 0,602996043 \\
\hline Śląskie & 43864 & 0,890806799 & 0,6487101 \\
\hline Świętokrzyskie & 30552 & $-0,301898594$ & $-0,530476415$ \\
\hline Warmińsko-mazurskie & 29677 & $-0,657818478$ & $-0,799292323$ \\
\hline Wielkopolskie & 43466 & 0,104065489 & $-0,072010897$ \\
\hline Zachodniopomorskie & 35006 & 16 & 16 \\
\hline
\end{tabular}

Źródło: opracowanie własne na podstawie danych zawartych w Roczniku statystycznym województw 2014,

GUS, Warszawa, 2014, s. 92-94 oraz na podstawie wyników badań PARP opublikowanych w: Regionalne Systemy Innowacji w Polsce - doświadczenia i perspektywy, materiały konferencyjne, Warszawa 2013.

Najwyższy wskaźnik innowacyjności „na wejściu” prezentują w kolejności następujące województwa: mazowieckie, śląskie, dolnośląskie, a najniższy wskaźnik innowacyjności województwo zachodniopomorskie. Wśród wskaźników „wejścia” wzięto pod uwagę: nakłady na działalność innowacyjną w przedsiębiorstwach przemysłowych w przeliczeniu na mieszkańca, nakłady na działalność innowacyjną w przedsiębiorstwach w sektorze usług, instytuty badawcze na 100 tys. podmiotów wpisanych do rejestru REGON, nakłady na 
działalność badawczo-rozwojową w dziedzinie nauk inżynieryjno-technicznych, relacje nakładów na działalność $\mathrm{B}+\mathrm{R}$ do $\mathrm{PKB}$, liczbę zatrudnionych $\mathrm{w} \mathrm{B}+\mathrm{R}$ $\mathrm{W}$ sektorze przedsiębiorstw, przedsiębiorstwa dysponujące internetem, liczbę studentów kierunków informatycznych, fizycznych, inżynieryjno-technicznych. Wskaźniki „wyjścia”, jakie wzięto do oceny innowacyjności regionów, to: udział przychodów netto ze sprzedaży produktów innowacyjnych w przychodach netto ze sprzedaży ogółem; liczba przedsiębiorstw, które prowadziły nowe lub istotnie ulepszone produkty; przedsiębiorstwa, które wprowadziły nowe lub ulepszone procesy; liczba wynalazków zgłoszonych przypadających na 1 mln ludności; udzielone patenty na $1 \mathrm{mln}$ ludności oraz high-technology w sekcji przetwórstwa przemysłowego. Liderami z najwyższymi wskaźnikami innowacyjności ,na wyjściu" są województwa: mazowieckie, dolnośląskie i śląskie, a najniższym zachodniopomorskie. Rozkład województw z punktu widzenia poszczególnych wskaźników jest dość różnicowany, widoczne są jednak pewne prawidłowości. $\mathrm{Na}$ wyższych miejscach w rankingach, według analizowanych wskaźników, znajdują się województwa, w których poziom rozwoju gospodarczego jest wyższy (wskaźnik PKB).

\section{Kierunki tworzenia efektywnego systemu zarządzania innowacjami w regionie}

W części pierwszej omówiono modele systemu zarządzania innowacjami. Przedstawione modele są bardzo zróżnicowane, dlatego konieczne staje się wykreowanie modelu łączącego długookresową krajową strategię rozwoju innowacji $\mathrm{z}$ regionalną wizją uwzględniającą priorytety lokalne.

Regionalne Systemy Innowacji skupiają przedsiębiorstwa, jednostki naukowo-badawcze oraz organizacje otoczenia okołobiznesowego, które kreują, transferują i implementują innowacje. Jak każdy rynek, tak i rynek innowacji charakteryzowany jest popytem na innowacje i ich podażą ${ }^{11}$. Podaż reprezentują jednostki administracji państwowej i regionalnej. Jednostki te powinny integrować struktury biznesu, organizacje społeczne, instytucje naukowo-badawcze, uczelnie wyższe, a także jednostki wspierające innowacyjność, takie jak klastry, parki technologiczne, centra transferu, firmy konsultingowe, fundusze ubezpieczeniowe, fundusze venture capital, banki.

Popyt na innowacje jest oczekiwaniem konsumentów nowych produktów i usług. Wykorzystanie informacji płynących od konsumentów oraz często

11 O. Oksanych, Regional growth factors innovativeness enterprises, Toyotarity - Organization's development strategies, Dniepropietrowsk 2011, s. 105-120. 
wykorzystanie ich pomysłów i gotowych rozwiązań ${ }^{12}$ (User-Driven) sprzyja lepszemu poznaniu ich oczekiwań i zapotrzebowaniu.

Wspieranie postaw proinnowacyjnych powinno przebiegać na różnym poziomie, począwszy od środowiska rodzinnego stymulującego tworzenie postaw proinnowacyjnych, poprzez system edukacji, skończywszy na tworzeniu klimatu organizacyjnego. Kreowanie proinnowacyjnych postaw społeczeństwa staje się priorytetem. Uczestnicy procesu innowacyjnego powinni charakteryzować się elastycznością i gotowością podejmowania wyzwań, a co za tym idzie - ryzyka, ponadto pozytywną wymianą interpersonalną, stymulacją intelektualną. Zarządzanie innowacjami może być skuteczne pod warunkiem zgodności interesów gospodarczych uczestników procesu. Potrzeba innowacji na każdym z trzech poziomów - państwowym, regionalnym i korporacyjnym - jest postrzegana inaczej. Na poziomie państwa innowacje są niezbędne dla rozwoju gospodarki, na poziomie regionu - determinują wzrost konkurencyjności, a co za tym idzie atrakcyjności inwestycyjnej. Natomiast na poziomie podmiotów gospodarczych innowacje są nieodzowne do budowy przewagi konkurencyjnej. W efektywnie działającym systemie zarządzania innowacjami muszą być jasno określone i przypisane funkcje, by uniknąć ich nakładania się.

Najważniejsze funkcje uczestników Regionalnego Systemu Innowacji przedstawiono w tabeli 2 .

Tabela 2. Funkcje uczestników Regionalnego Systemu Innowacji

\begin{tabular}{|c|l|}
\hline \multicolumn{1}{|c|}{ Uczestnicy RSI } & \multicolumn{1}{c|}{ Sprawowane funkcje } \\
\hline \multirow{3}{*}{ Władze państwowe } & $\begin{array}{l}\text { Podejmowanie decyzji dotycząceych RFI i podanie do wiadomości } \\
\text { uczestnikom RSI } \\
\text { Wspieranie działań proinnowacyjnych }\end{array}$ \\
\cline { 2 - 3 } Władze regionalne & $\begin{array}{l}\text { Inicjowanie działań intensyfikujących działalność innowacyjną kraju } \\
\text { i regionów }\end{array}$ \\
\hline & $\begin{array}{l}\text { Informowanie uczestników RSI o decyzjach władz lokalnych } \\
\text { dotyczących uchwał RFI }\end{array}$ \\
\cline { 2 - 3 } & $\begin{array}{l}\text { Inicjowanie działań na rzecz intensyfikacji działalności innowacyjnej } \\
\text { regionu }\end{array}$ \\
\cline { 2 - 3 } & $\begin{array}{l}\text { Otrzymywanie informacji o bieżącym stanie i problemach } \\
\text { innowacyjności w regionie }\end{array}$ \\
\hline
\end{tabular}

12 E. Wojnicka, Popytowe podejście do innowacji - charakterystyka koncepcji, http://pi.gov.pl/PARPFiles/file/ INNOWACYJNA_FIRMA/KIP/Prezentacje/E_Wojnicka(1).pdf [dostęp 8.07.2015]. 


\begin{tabular}{|l|l|}
\hline \multicolumn{1}{|c|}{ Uczestnicy RSI } & \multicolumn{1}{c|}{ Sprawowane funkcje } \\
\hline \multirow{4}{*}{ Jednostki B+R } & $\begin{array}{l}\text { Działalność B+R i świadczenie usług (ekspertyzy, doradztwo, } \\
\text { szkolenia) }\end{array}$ \\
\cline { 2 - 2 } & $\begin{array}{l}\text { Opracowanie dokumentów planistycznych z uwzględnieniem potrzeb } \\
\text { regionu }\end{array}$ \\
\cline { 2 - 2 } & Informowanie uczestników RSI o produktach innowacyjnych \\
\hline \multirow{2}{*}{$\begin{array}{l}\text { Jednostki otoczenia } \\
\text { okołobiznesowego }\end{array}$} & Transfer wiedzy i informacji o innowacyjnych produktach \\
\cline { 2 - 2 } $\begin{array}{l}\text { Forum innowacji } \\
\text { (w którego } \\
\text { skład wchodzą } \\
\text { przedstawiciele ww. } \\
\text { uczestników) }\end{array}$ & $\begin{array}{l}\text { Wyboraca z władzami centralnymi i regionalnymi w zakresie } \\
\text { Kontroling i ocena działalności Komitetu RSI. } \\
\text { Zatwierdzanie budżetu RSI } \\
\text { Intensyfikowanie działań innowacyjnych regionu }\end{array}$ \\
\cline { 2 - 3 } & Kreowanie postaw proinnowacyjnych wśród mieszkańców regionu \\
\hline \multirow{3}{*}{ Zarząd RSI } & Operacyjne zarządzanie RSI \\
\cline { 2 - 3 } & Opracowanie projektów decyzji Forum Innowacji \\
\cline { 2 - 2 } & $\begin{array}{l}\text { Sporządzanie i prowadzenie dokumentacji dotyczących działalności } \\
\text { i wyników Forum Innowacji }\end{array}$ \\
\hline
\end{tabular}

Źródło: M. Słomińska-Okła, Zasady formowania organizacyjno-ekonomicznego mechanizmu wsparcia innowacji w regionie, w: Wspótczesne wyzwania rozwojowe regionów ze szczególnym uwzględnieniem województwa świętokrzyskiego, red. M. Kotowska-Jelonek, Wydawnictwo Politechniki Świętokrzyskiej, Kielce 2014.

Na rysunku 1 przedstawiono efekt wzrostu innowacyjności dla poszczególnych uczestników procesu, jakie mają szansę zaistnieć w sprawnie działającym systemie zarządzania innowacjami.

W celu podniesienia poziomu innowacyjności regionu należy w jak największym stopniu korzystać ze środków europejskich, które w dużym stopniu współfinansują realizację projektów. Ponadto realizacja jednego projektu skutkuje podejmowaniem kolejnego przedsięwzięcia o charakterze innowacyjnym. Mowa tu o występowaniu i wykorzystaniu tzw. efektu mnożnikowego (multiplier effect). Przy realizacji projektów innowacyjnych współfinansowanych ze środków europejskich beneficjent nabiera doświadczenia, co może skutkować przygotowaniem kolejnych projektów o coraz wyższej jakości i skuteczności w aplikowaniu o środki z zewnętrznych źródeł. Dodatkowo realizacja projektu innowacyjnego skutkuje wzrostem zainteresowania pozyskiwaniem środków zewnętrznych na realizacje projektów. W tym przypadku mówimy o występowaniu efektu doświadczenia (experience effect). 


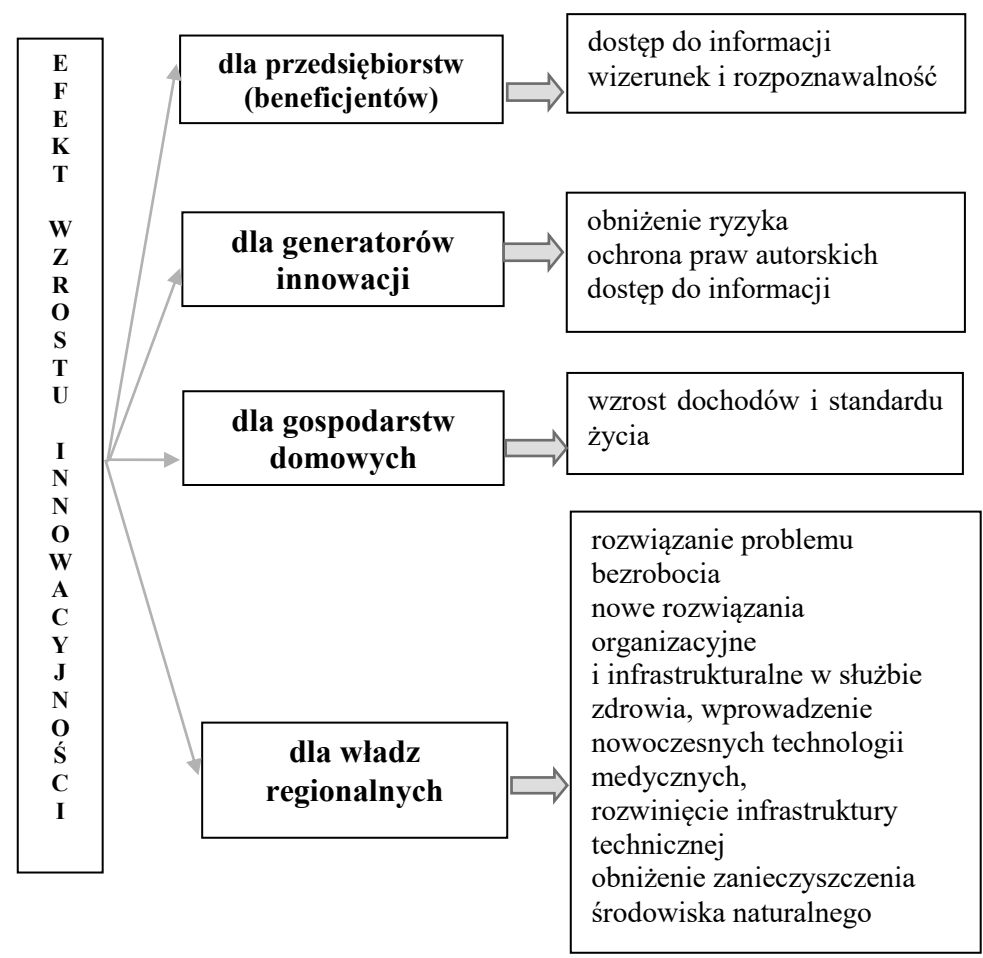

Rysunek 1. Efekt wzrostu innowacyjności dla uczestników procesu innowacyjnego

Źródło: M. Słomińska-Okła, Zasady kreowania systemu innowacyjności w regionie, w: Współczesne uwarunkowania rozwoju społeczno-gospodarczego. Świat - Polska - Region Świętokrzyski, red. A. Maciąg, PiS Agencja Wydawniczo-Poligraficzna, Skarżysko-Kamienna 2014.

Do zabiegania o środki finansowe na realizację projektów przekonują nie tylko dobre praktyki, lecz także świadomość prawdopodobieństwa wystąpienia efektu zdarzeń niezależnych (deadweight effect), jakie zostałyby osiągnięte w sytuacji nieuzyskania przez beneficjenta wsparcia. Kolejną przesłanką ubiegania się o dofinansowanie unijne jest efekt kosztów transakcyjnych. Na poziomie beneficjenta efekt ten obejmuje: koszty (finansowe i pozafinansowe) związane z przygotowaniem wniosku o wsparcie, sprawozdawczością, rozliczeniem dotacji oraz inne koszty (np. wynikające $\mathrm{z}$ konieczności realizacji projektu zgodnie z przyjętym harmonogramem). Na poziomie instytucji są to m.in. koszty związane z kontrolą, zarządzaniem, wdrożeniem i pośredniczeniem. 


\section{Podsumowanie}

W artykule zwrócono uwagę na korelację niskiego poziomu innowacyjności z silnym zróżnicowaniem pomiędzy regionami w Polsce. Omówiono także dokumenty strategiczne, w których cele przenikają się wzajemnie i są ukierunkowane na tworzenie i wzmacnianie regionalnych systemów innowacji.

Regionalne Systemy Innowacji zawierają ściśle określone cele związane z przedsiębiorczością. Brakuje w nich jednak celów związanych z działaniami transformującymi wyniki badań i potencjału badawczego w innowacyjne towary i usługi. Każda strategia regionalna powinny kłaść nacisk na tworzenie instrumentów finansowych mających w ofercie fundusze venture capital i speed capital a także wspierać formowanie firm typu start-up.

Regionalne Systemy Innowacji zmieniły świadomość wszystkich interesariuszy i uprościły relacje zachodzące pomiędzy nimi. Odzwierciedleniem takiego zaangażowania na poziomie regionalnym jest Regionalne Forum Innowacji uwzględniające zapewnienie bilansu interesów poszczególnych uczestników.

Koncepcyjne podejście do rozwoju systemu zarządzania na poziomie regionalnym może być wykorzystane przez regionalne władze i instytucje zajmujące się zarządzaniem innowacjami.

\section{Literatura}

Bessant J., Pavitt K., Tidd J., Managing Innovation - Integrating Technological, Market and Organizational Change, Wiley and Sons, Chichester 2005.

Karlik M., Zarzadzanie innowacjami w przedsiębiorstwie, Poltext, Warszawa 2012.

Kucińska-Landwójtowicz A., Podejście procesowe $w$ zarządzaniu innowacjami, Oficyna Wydawnicza Politechniki Opolskiej, Opole 2013, http://www.ptzp.org.pl/ files/konferencje/kzz/artyk_pdf_2013/p016.pdf

Łunarski J., System zarzadzania innowacjami, w: Zarzadzanie innowacjami - system zarządzania innowacjami, Oficyna Wydawnicza Politechniki Rzeszowskiej, Rzeszów 2007.

Oksanych O., Regional growth factors innovativeness enterprises, Toyotarity - Organization's development strategies, Dniepropietrowsk 2011.

O’Sullivan D., Dooley L., Applying innovation, SAGE Publications, Thousand Oaks, California 2008.

Regionalne Systemy Innowacji w Polsce - doświadczenia i perspektywy, materiały konferencyjne, PARP Warszawa 2013. 


\title{
THE DEVELOPMENT OF INNOVATION MANAGEMENT SYSTEM DETERMINANT OF GROWTH COMPETITIVENESS OF THE REGION
}

\begin{abstract}
The subject of discussion in the article is the impact of innovation management system to increase the competitiveness of regions. Analyzing the literature highlighted the importance of innovation systems at regional level.
\end{abstract}

Translated by Maria Słomińska-Okła

Keywords: determinants of regional competitiveness growth, RSI, innovation management

JEL code: 030 
